\title{
História da Educação e Literatura: possibilidades de relações
}

\section{Literature and History of Education: possible relationships}

\author{
Arlete de Jesus Brito" \\ Maria Augusta Ribeiro**
}

\begin{abstract}
Resumo
Nas últimas décadas do século XX, a história da educação, bem como a da educação matemática, tem como referenciais, prioritariamente, a história nova e a história cultural. Tais referenciais vêm ocasionando mudanças, não apenas nos objetos de pesquisa, mas também nos métodos e fontes utilizados por tais histórias. Apesar da diversificação de fontes, há algumas que ainda não têm feito, sistematicamente, parte das pesquisas nessa área, tais como os textos de ficção. Segundo Lajolo (1997), a literatura é radar e espelho dos valores, emoções, sentimentos e pontos de vista das sociedades, portanto é possível questionar textos literários com perguntas que visem à elaboração de uma narrativa histórica. Neste artigo, os rastros e fios deixados pelos textos literários Novelas Paulistanas e Memórias de um Sargento de Milícias nos conduziram a uma pesquisa histórica, em fontes secundárias, com o intuito de compreender parte do processo educacional escolar do Brasil Império, no Rio de Janeiro, e da Primeira República, em São Paulo.
\end{abstract}

Palavras-chave: História da Educação. História da Educação Matemática. Literatura. Indícios.

\footnotetext{
* Doutora em Educação pela Universidade Estadual de Campinas (UNICAMP) e Livre Docente pela Universidade Estadual Paulista (UNESP). Professora do Departamento de Educação, do Programa de Pós-Graduação de Educação (PPGEd) e do Programa de Pós-Graduação em Educação Matemática (PPGEM) da Universidade Estadual Paulista (UNESP). Endereço para correspondência: Av. 24 A, n. 1515, Bela Vista, CEP: 13506-900, Rio Claro, SP, Brasil. E-mail: arlete@rc.unesp.br.

** Doutora em Ciências da Comunicação pela Universidade de São Paulo (USP). Professora Doutora do Departamento de Educação da Universidade Estadual Paulista (UNESP) e do do Programa de Pós-Graduação de Educação (PPGEd) da Universidade Estadual Paulista (UNESP). Endereço para correspondência: Av. 24 A, 1515, Bela Vista, CEP: 13506-900, Rio Claro, SP, Brasil. E-mail: mahwr@rc.unesp.br.
} 


\begin{abstract}
In the last decades of the $20^{\text {th }}$ Century, the History of the Education, as well as that of Mathematical Education have used the background of the New History and Cultural History. It has changed its objects, methods and sources. Despite the diversification of sources, some of them have still not been used systematically in research. This is the situation with regard to fiction texts. According to Lajolo (1997), literature is the radar and mirror of the values, emotions, feelings and point of view of societies. Therefore we can pose questions to literary texts to seek historical narratives. In this paper, parts of the literary texts Novelas Paulistanas and Memórias de um Sargento de Milícias have led us to historical research in secondary sources. We aim to contribute to understanding of the Brazilian Empire's process of school education, in Rio de Janeiro, and of the First Republic's educational process, in São Paulo.
\end{abstract}

Keywords: History of Education. History of Mathematical Education. Literature. Sign.

\title{
1 Introdução
}

A história da educação, no Brasil, não é recente. Segundo Vidal e Faria Filho (2005), desde a segunda metade do século XIX já eram produzidos tratados com esse tema. Nessa época, sob os auspícios da história política rankeana ${ }^{1}$, as fontes utilizadas na pesquisa histórica eram aqueles textos considerados documentos com a chancela política, os quais precisavam passar pela crítica documental que pretendia verificar sua autenticidade. Assim, naquelas primeiras Histórias da Educação, as fontes eram, prioritariamente, reformas educacionais e decretos governamentais.

A ideia de que os documentos oficiais não conteriam elementos ideológicos, em detrimento dos demais textos, começou a ser questionada por historiadores desde o início do século XX e foi, por fim, abandonada. Sobre isso, White (1987) afirma que

considerados como evidência histórica, todos os textos são igualmente entrelaçados com elementos ideológicos ou, o que significa a mesma coisa, são igualmente transparentes, fiéis ou evidentes no que eles podem contarnos sobre o "clima mental" (aqui construído variavelmente) em que eles surgiram (p. 282).

\footnotetext{
${ }^{1}$ Termo utilizado para se referir à História como foi proposta por Leopold Von Ranke (1795 1886), historiador alemão.
} 
Segundo Chartier (1988) e Burke (2002), desde o início do século XX, a disciplina história vem-se aproximando de outros campos científicos tais como a sociologia, a antropologia, a economia, a geografia e, mais atualmente, a linguística. Com tal aproximação, ocorreram mudanças nos métodos de pesquisa histórica, além da ampliação do campo de possíveis objetos a serem investigados e, portanto, das fontes documentais utilizadas nesse processo. Entre tais fontes, encontram-se os textos literários. Conforme Chartier (2007)

Atualmente, sem dúvida mais que em 1998, os historiadores sabem que o conhecimento que produzem não é mais que uma das modalidades da relação que as sociedades mantêm com o passado. As obras de ficção, ao menos algumas delas, e a memória, seja ela coletiva ou individual, também conferem uma presença ao passado. (p.21).

A partir das décadas de 1970 e 1980, a história da educação começou a ter como referenciais, prioritariamente, a História Nova e a História Cultural. Esse mesmo movimento é apontado por Miguel e Miorim (2002), no que se refere à história da educação matemática. Tais novos referenciais vêm ocasionando mudanças, não apenas nos objetos de pesquisa, mas também nos métodos e fontes utilizados pela história da educação. Entre as novas fontes podemos citar os diários de classe, os livros didáticos e as atas de reuniões escolares.

No entanto, há outras fontes que ainda não têm feito, sistematicamente, parte das pesquisas nessa área, tais como os textos de ficção, apesar de já haver investigações em história da educação matemática que abordam de diferentes modos a relação entre história, ficção e literatura, veja-se, por exemplo, os textos de Silva (2006), Garnica (2008), Brito (2011) e Cury (2011). Este artigo tem o objetivo de contribuir com essas discussões, apesar de ele se aproximar muito mais da história da educação que propriamente da história da educação matemática. Garnica (2010) indica esses movimentos de aproximação/ afastamento necessários a esse último campo de pesquisa, uma vez que áreas tais como a História, Educação, Sociologia e outras possuem um largo histórico de compreensões tanto do espaço escolar quanto da sociedade. Segundo tal autor,

Defendemos, portanto, que cabe aos educadores matemáticos a apropriação de uma gama imensa de compreensões já disponíveis de modo a formar nossas estratégias de pesquisa e configurar nossos objetos. Passa 
por isso, é claro, a necessidade de compreendermos e nos familiarizarmos com técnicas, questionamentos e fundamentações que, quando dominadas em sua forma de produção, são trazidas para a Educação Matemática constituindo-se em algo novo, gerado no processo de fusão criativa advindo de interlocuções várias (GARNICA, 2010, p. 77).

Assim, o texto aqui apresentado traz à tona discussões atuais, no campo da história, acerca dos testemunhos deixados pela literatura e, ao buscar exemplos de como a história da educação pode se beneficiar de tais discussões, indica possibilidades de inquérito de tais testemunhos na realização de histórias da educação matemática. Sobre a existência de testemunhos históricos involuntários acerca dos costumes e usos em textos de ficção, Ginzburg (2007) comenta:

Ler os testemunhos históricos a contrapelo, como Walter Benjamin sugeria, contra as intenções de quem os produziu - embora, naturalmente, deva-se levar em conta essas intenções - significa supor que todo texto inclui elementos incontrolados. Isso também vale para textos literários que pretendem se constituir numa realidade autônoma. Até neles se insinua algo de opaco. Essas zonas opacas são alguns dos rastros que um texto (qualquer texto) deixa atrás de si. (p. 11-12).

Ainda segundo esse autor, no século XVII foi formulada, pela primeira vez, a discussão sobre a possibilidade de inquérito do passado por meio da leitura de romances, quando Jean Chapelain (1595 - 1674) escreveu em seu livro, Sobre a leitura de velhos romances, que seria possível observar antigos costumes tanto por meio do romance de cavalaria Lancelot quanto a partir do texto histórico Desde a fundação da cidade, de Tito Lívio (sec. I a.C.).

Comparar Lancelot e Lívio seria absurdo, assim como seria absurdo comparar Virgílio e Lívio, o falso e o verdadeiro. E todavia ouso dizer que, mesmo se Lancelot, sendo baseado em fatos imaginários, não pode ser comparado a Lívio como exemplo de narração verdadeira [par la vérité de l'histoire], pode sê-lo em outro plano, como imagem verdadeira de usos e costumes [par la vérité dês moeurs et des coutumes] (CHAPELAIN, 1936 apud GINZBURG, 2007, p. 81).

Segundo Lajolo (1997), a literatura é radar e espelho dos valores, 
emoções, sentimentos e pontos de vista das sociedades. Decorre dessa constatação, a possibilidade de se questionar textos literários com perguntas que visem à elaboração de uma narrativa histórica. Ainda sobre tal possibilidade, Almeida, na apresentação do livro A educação na literatura do século XIX, de Maria Elizabeth Xavier (2008) afirma que

interpretar obras de arte, as literárias, por exemplo, como fonte de história e expressões da sociedade de seu tempo é algo que se discute há muito tempo. Dado o caráter de criação, ambigüidade, complexidade alegórica, e outras características da obra artística, ela apresenta ao intelectual uma diversidade de possibilidades interpretativas, tanto ideológicas como formais (ALMEIDA, 2008, p. 8).

No entanto, Almeida nos alerta que "o problema do intérprete acadêmico é como chegar a essa visão sem reduzir a obra aos conceitos estabelecidos de uma teoria já aceita e praticada há muitos anos" (ALMEIDA, 2008, p. 9). Concordamos com esse autor, pois a obra de arte, enquanto arte, não se limita a indicar usos da época em que foi elaborada.

Não estamos afirmando que a história e a literatura possuem o mesmo estatuto epistemológico. Há autores atuais que defendem que elas teriam aquele mesmo estatuto, já que ambas, desde a Antiguidade, utilizam, em suas exposições, o estilo narrativo, ou a retórica, o que lhes conferiria um caráter eminentemente subjetivo e valorativo, como por exemplo, nas narrações históricas de Tucídides (sec. I a.C.) (WHITE, 1987). O que tais autores pretendem, a princípio, é oporse ao caráter cientificista de objetividade defendido por algumas linhas historiográficas, como por exemplo, a rankeana, já citada aqui.

Ginzburg (2007) opõe-se ao modo de entender as relações entre história e literatura que pretende igualá-las, pois a história tem um compromisso com a realidade, seja lá o que se entenda por esse termo. Para esse autor, mesmo na Antiguidade, história e literatura se distanciavam, pois a retórica aristotélica, utilizada em narrações históricas, pressupunha a prova, fosse material ou argumentativa, obtida com base em indícios. Lima (2006) aproxima ambos os modos de narrativa, mas os diferencia. Citando Hornblower, afirma que "com Tucídides, bem como com Heródoto, é um erro supor que um procedimento literário [isto é, a retórica] é algo inconsistente com um relato verdadeiro, pode ser antes um modo estilizado de apresentar o que é verdade" (HORNBLOWER, 1987 apud LIMA, 2006, p. 92), ou seja, o uso da retórica pela história não necessariamente torna essa última uma ficção. 
Concordamos com Lima quando pondera que a história tem a verdade como aporia, entendendo verdade como discursos criados e aceitos como verdadeiros por diferentes sociedades. Porque tais discursos variam historicamente, a história se aproxima da literatura, porém, a história não é ficção, pois naquela a imaginação é serva do entendimento do acontecido, "a imaginação atua na escrita da história, mas não é seu lastro” (LIMA, 2006, p. 65), enquanto na literatura ocorreria o inverso. Sobre isso, Aristóteles, citado por Ginzburg (2007), afirmava que a obra do poeta, ao contrário da do historiador, consistiria em relatar fatos possíveis, no âmbito do verossímil e do necessário. Ainda sobre isso, Machado de Assis, em seus escritos como crítico de arte, afirmava que a literatura poderia servir-se da história em suas composições, no entanto, aquela jamais seria uma reprodução desta (RIBEIRO, 1989), porque a literatura é uma forma de arte e como tal não se atém ao particular, como a história, mas busca o universal.

Dentre os textos literários, escolhemos dois de ficção autobiográfica que exemplificam, por seus temas, a aproximação entre literatura e história. Olhos verdes, de Marguerite Duras e Homens e não, de Elio Vittorini. O primeiro narra as experiências da autora, na França, nos movimentos de resistência ao nazi-facismo, o segundo as do autor nesses mesmos movimentos, na Itália. Tais obras recorrem à memória e estampam fatos ocorridos na guerra, aproximandose do fazer historiográfico, mas ambos os textos vão além. Trazem-nos as dores humanas das perdas e das escolhas difíceis, dores passíveis de serem vividas por qualquer pessoa, em qualquer época e sociedade, ou seja, por serem uma forma de arte, a da palavra, tocam o universal.

Portanto, mesmo ocorrendo proximidades entre a narrativa historiográfica e a da ficção, para nós, elas não são igualáveis no que se refere aos limites epistemológicos, até porque ambas possuem modos de elaboração e de validação diferentes entre si, mesmo sendo tais modos historicamente variáveis. Entretanto, uma pode servir de inspiração ou de fonte para a outra, como por exemplo, nos romances de época, nos quais a história serve de pano de fundo para a literatura.

Aqui, discutiremos algumas possibilidades de fazer história com base em fontes literárias. Concordamos com Ginzburg (2007) quando defende que as obras literárias têm muito a nos contar sobre os costumes da época em que foram escritas, muito mais por meio das vozes incontroladas dos textos, do que pela análise da intenção de quem os produziu.

Para isso, vamos buscar indícios da história da educação em textos de diferentes épocas, quais sejam, Memórias de um sargento de milícias, de Manuel 
Antonio de Almeida, publicado pela primeira vez em 1854 e Novelas Paulistanas, de Antonio de Alcântara Machado, composto por obras publicadas em 1927 (Brás, Bexiga e Barra Funda), 1928 (Laranja da China) e 1936 (Mana Maria). Tais indícios nos colocam à busca de compreensões, o que nos leva a elaborar interpretações históricas.

\section{Novelas paulistanas}

Antonio de Alcântara Machado (1901 - 1935) nasceu em São Paulo, em uma família abastada da qual emergiram vários políticos, tais como seu bisavô Brigadeiro José Joaquim Machado d'Oliveira (1790 - 1867), seu pai, José de Alcântara Machado d'Oliveira (1875 - 1941) e seu irmão Basílio Machado Neto (1900 - 1968). Seus primeiros estudos foram no colégio Stafford, escola frequentada pela elite da cidade de São Paulo, instalado em um casarão que havia sido residência de Santos Dumont (1873 - 1932). Frequentou, também, o Ginásio de São Bento, antes de ingressar na Faculdade de Direito de São Paulo. Trabalhou algum tempo como advogado, mas a profissão exercida desde os dezenove anos foi a de jornalista. Esteve à frente da Revista de Antropofagia (1928 - 1929) e fundou, com Paulo Prado e Mario de Andrade, a Revista Nova (1931 - 1932) que propunha discutir e difundir o movimento literário do Modernismo. Em 1927, publicou Brás, Bexiga e Barra Funda que, segundo seu autor, "não nasceu livro, nasceu jornal. Estes contos não nasceram contos: nasceram notícias" (MACHADO, 1978, p. 7).

Em tais contos que nasceram notícias bem como nos demais escritos por ele, como os do livro Laranja da China (1928), encontramos indícios sobre a vida cotidiana tanto de migrantes italianos quanto da burguesia paulistana, da década de 1920, o que vai ao encontro do que asseveram Alencastro e Renaux (1998, p. 295): "o assunto [migração estrangeira] atravessa todo o debate político brasileiro da Independência até a Revolução de 1930, e impregna muitas das grandes e pequenas obras literárias e ensaísticas brasileiras”.

As diferenças e as proximidades da educação dos migrantes e seus descendentes e da burguesia paulistana também estão nos textos de Alcântara Machado. Vejamos, pois, alguns trechos em que há referência à escola, nesses textos.

O conto Tiro-de-Guerra $N^{o} 35$ inicia-se da seguinte maneira:

No Grupo Escolar da Barra Funda, Aristodemo Guggiani aprendeu em três anos a roubar com perfeição no jogo de 
bolinhas (garantindo o tostão para o sorvete) e ficou sabendo na ponta da língua que o Brasil foi descoberto sem querer e é o país maior, mais belo e rico do mundo. $\mathrm{O}$ professor Seu Serafim todos os dias ao encerrar as aulas limpava os ouvidos com o canivete (brinde do Chalé da Boa Sorte) e dizia olhando o relógio:

- Antes de nos separarmos, meus jovens discentes, meditemos uns instantes no porvir da nossa idolatrada pátria.

Depois, regia o hino nacional. Em seguida o da bandeira. O pessoal entoava os dois engolindo metade das estrofes. (MACHADO, 1978, p. 18)

Conforme referências do Memorial de Educação do Governo de São Paulo, o grupo Escolar da Barra Funda foi instalado em 1903 naquele bairro, quando ocorreu a junção da seção masculina do Grupo Escolar Santa Ephigenia e de uma seção feminina. Em seus inícios, abrigava 250 alunos em 10 salas, número que foi ampliado, em 1910, para atender à necessidade crescente da população em idade escolar. Atualmente, denomina-se Escola Estadual Antonio Prado. Ao que nos indica o sobrenome de Aristodemo, à época em que foi escrito o texto de Machado (1978), era uma escola frequentada também por descendentes de migrantes pobres.

Pode causar estranhamento saber que crianças, filhos de migrantes, frequentavam grupos escolares nacionais ${ }^{2}$ em bairros paulistanos, em 1920, época em que cerca de $71 \%$ da população brasileira, da faixa etária de 5 anos ou mais, e 64,7\% da do estado de São Paulo eram não alfabetizadas. Causa estranhamento maior ainda, quando consideramos que, na cidade de São Paulo, até o ano de 1936, havia apenas três ginásios do Estado, apesar de haver mais de quarenta particulares, o que indica uma educação mais voltada para as elites. No entanto, devemos lembrar que, em 1920, Sampaio Dória, com o propósito de combater o analfabetismo e de integrar os imigrantes, em São Paulo, realizou uma reforma educacional, que foi uma entre várias subsequentes influenciadas por muitos fatores, entre eles, o processo de industrialização do país, a necessidade de qualificação da mão de obra fabril, o desejo de acompanhar as mudanças que ocorriam no mundo em termos de acesso à educação e a disseminação de um ideal patriótico, voltado para a nacionalização do país, principalmente entre

\footnotetext{
${ }^{2}$ Com esse termo queremos diferenciar tais escolas daquelas fundadas e administradas por migrantes, nas quais se ensinava não apenas a cultura dos países de origem dos mesmos, mas inclusive a língua na qual eram ministradas as aulas, era a daqueles países.
} 
migrantes (RIBEIRO, 2011). Sobre esse último fator, Manuel Bonfim, no final do século XIX e início do XX, alertava para "a urgência de se reformular o ensino primário, unificando-o e nacionalizando a escola primária" (SCHWARTZMAN; BOMENY; COSTA, 1984, p. 73). A preocupação de Bonfim está relacionada ao número de migrantes vindos para o Brasil, entre finais do século XIX e início do XX, que mantinham sua cultura e língua, o que dificultava o processo de nacionalização pretendido pelo governo e necessário à jovem República do Brasil.

A migração italiana para o Brasil iniciou-se no século XIX. Segundo Alencastro e Renaux (1998, p. 314) "nos anos 1890, a migração italiana essencialmente dirigida para São Paulo e financiada por subvenções do governo provincial e depois do governo estadual - atinge seu pique histórico: 85 mil italianos entram nesse estado em 1895". Muitos migrantes italianos e seus descendentes saíram do campo e se instalaram no bairro da zona oeste de São Paulo, Barra Funda, que se originou do loteamento da fazenda de Antonio da Silva Prado, nas primeiras décadas do século XX. Logo após tal loteamento, lá foram viver para trabalhar, principalmente, em oficinas mecânicas e serrarias que atendiam à elite moradora do bairro vizinho, Campos Elíseos. Alcântara Machado refere-se a essas ocupações de migrantes italianos quando retrata o pequeno Gaetaninho ${ }^{3}$ sonhando em andar de carro e quando situa o primeiro trabalho de Aristodemo: a oficina mecânica do cunhado. Assim, percebemos que a Barra Funda era um bairro proletário de migrantes, o que nos faz compreender o porquê da necessidade de o personagem Aristodemo ter que ganhar no jogo de bolinhas para garantir o tostão do sorvete e o porquê aprendia, na escola, que o Brasil seria o país maior, mais belo e mais rico do mundo e nela tinha que entoar, todos os dias, os hinos nacional e da bandeira, da idolatrada pátria.

Nessa época, leis estaduais e federais ${ }^{4}$ foram elaboradas com o intuito de garantir que a escola incentivasse o nacionalismo em seus alunos, fosse por meio de conteúdos de educação cívica aprendidos na ponta da língua, que tinham por meta glorificar o país e seus símbolos, ou da obrigatoriedade do português em escolas de migrantes, pois se acreditava que a unificação do país pressupunha a da língua. Devemos lembrar que até a Era Vargas, apesar de leis que obrigavam o ensino de português nas escolas de migrantes, muitas delas

\footnotetext{
${ }^{3}$ Gaetaninho, personagem do conto Gaetaninho de Brás, Bexiga e Barra Funda.

${ }^{4}$ Veja-se, por exemplo, Lei n. 489, de 29 de dezembro de 1896, do Estado de São Paulo; Lei n. 723, de 03 de abril de 1907 do Estado do Paraná e o Decreto-Lei no. 406, de 04 de maio de 1938 sancionado em nível federal. Sobre o caso específico da interferência do processo de nacionalização em escolas alemães, no Brasil, veja-se Schubring (2003).
} 
mantinham como língua materna a de seus países de origem. Schwartzman Bomeny e Costa (1984) citam documento de 1921, no qual se afirma que

O espírito dessas crianças brasileiras, formado em língua, nos costumes, nas tradições dos pais, só poderia tender para a pátria de origem, constituindo um empecilho à coesão nacional. Mesmo na raça latina e assimilável como é a italiana, nota-se uma grande tendência para conservar a língua e os costumes, quando formando regulares aglomerações (SCHWARTZMAN et al., 1984, p. 73).

Segundo Orlandi, Lajolo e Ianni (1997, p. 26), no início do século XX, "todo o projeto ortográfico traduz a ilusão necessária da unidade da língua como unidade de um povo". Além disso, segundo Lourenço e Razzini (2010), o abrasileiramento do currículo das escolas de migrantes possibilitava amenizar o problema da falta de vagas em escolas públicas.

No entanto, pelo observado no conto Nacionalidade, à época em que foi escrito Brás, Bexiga e Barra Funda, nem todos os descendentes de migrantes faziam questão de manter o idioma do país de onde vieram seus pais. O barbeiro Tranquillo Zampinetti lia os comunicados de guerra do Fanfulla ${ }^{5}$ :

La fulminante investita dei nostri bravi bersaglieri ha ridotto le posizione nemiche in un vero amazzo di rovine. Nel campo di battaglia sono restati circa cento e novanta nemici. Dalla nostra parte abbiamo perduto due cavalli ed è rimasto ferito un bravo soldato [...]

Mas tinha um desgosto. Desgosto patriótico e doméstico. Tanto o Lorenzo como o Bruno (Russinho para a saparia do Brás) não queriam saber de falar italiano. Nem brincando! (MACHADO, 1978, p. 46).

Se por um lado, os contos de Alcântara Machado nos remetem ao processo de nacionalização e de ideais de patriotismo da época em que foram escritos, por outro, trazem uma ironia que indica uma crítica em relação a esses ideais como, por exemplo, na frase "o Brasil foi descoberto sem querer e é o país maior, mais belo e mais rico do mundo". Esse mesmo olhar corrosivo sobre o patriotismo nacional é percebido, por exemplo, no conto O patriota Washington, do livro Laranja da China

Cercado pelos filhos escrevera na [folha] do dia 15 [do calendário]: Viva o Brasil! [...]

\footnotetext{
${ }^{5} \mathrm{O}$ jornal Fanfulla foi fundado em 1893 e, à época dos textos de Alcântara Machado, era o principal representante da imprensa italiana no Brasil.
} 
O doutor ${ }^{6}$ é de fato: brasileiro graças a Deus. Onde deseja nascer? No Brasil, é claro.

Ao lado dele a mulher é assim assim. Os filhos sabem de cor o hino nacional. Só que ainda não pegaram bem a música. Em todo o caso cantam às vezes durante a sobremesa para o doutor ouvir (MACHADO, 1978, p. 56).

Não podemos nos esquecer que Alcântara Machado participou ativamente, inclusive com sua literatura, do movimento modernista que, em seus primeiros tempos, questionava uma identidade brasileira pura e pressupunha a assimilação antropofágica das tendências culturais e artísticas da vanguarda europeia da época. Mario de Andrade, apesar de propor a retomada das raízes da cultura popular brasileira para superar os formalismos da cultura erudita de então, se opunha a um nacionalismo crivado pelo culto aos símbolos e líderes da pátria. Daí que o pessoal entoava os dois [hinos] engolindo metade das estrofes.

Essa cultura erudita europeia, questionada pelos adeptos do movimento modernista, estava à disposição dos filhos da elite paulistana educada em ginásios como, por exemplo, o de São Bento. É lá que inicia seus estudos, Januário, afilhado do "Excelentíssimo Senhor Coronel Juca", do conto Notas Biográficas do Novo Deputado, do livro Brás, Bexiga e Barra Funda.

Todo compenetrado, de pescoço duro e passo duro, Januário alcançou o coronel.

A meninada entrava no Ginásio de São Bento em silêncio e beijava a mão do Senhor Reitor. Depois disparava pelos corredores jogando os chapéus no ar. As aulas de portas abertas esperavam de carteiras vazias. O berreiro sufocava o apito dos vigilantes (MACHADO, 1978, p. 38).

Apesar da algazarra das crianças nos corredores, Machado nos fala de uma disciplina rígida, desde o portão de entrada do Gymnasio de São Bento, fundado em 1903, no centro da cidade de São Paulo, no mesmo local onde, em 1598, foi erguida a primeira ermida beneditina entre os rios Anhangabaú e Tamanduateí. Essa disciplina está expressa na fala de dona Nequinha a seu afilhado, Januário, quando esse se dirige a seu primeiro dia de aula: "Vá, meu filhinho. E tenha muito juízo, heim? Seja muito respeitador” (MACHADO, 1978, p. 38).

${ }^{6} \mathrm{O}$ citado doutor é o personagem Washington Coelho Penteado, patriota deslumbrado com o progresso do país. 
Provavelmente para atender às mudanças do ensino secundário impostas pela Reforma Capanema, de 1942, aquela instituição de ensino, em 1943, passou a se denominar Colégio de São Bento, pois com tal reforma, o ensino secundário passou a ser dividido em Ginásio com quatro anos de duração e Colégio, com três. Esse último estava subdividido em Clássico e Científico e tinha por objetivo preparar o estudante para ingressar na universidade (RIBEIRO, 2011). Assim, a mudança de nome para Colégio de São Bento talvez tenha ocorrido porque essa instituição optou por formar os jovens paulistanos que teriam acesso ao ensino superior. Ali, estudaram personagens da elite política e cultural brasileira, tais como Francisco Prestes Maia (1896 - 1965), Oswald de Andrade (1890 1954), Sergio Buarque de Holanda (1902 - 1982) e, como já afirmamos, o próprio Alcântara Machado.

Em 1906, o Ginásio de São Bento abrigou um internato. Nos finais do século XIX e inícios do XX, havia internatos destinados à população carente, mas também havia aqueles destinados à formação religiosa e os voltados para os filhos de famílias abastadas. Mas o órfão Januário não foi enviado para o internato de São Bento, que, à época em que foi escrito o conto, não existia mais. O que seus padrinhos queriam, da escola, é que esta o provesse de uma formação católica, o que não seria garantido em escolas públicas do período. Desde o início da República havia, por parte da Igreja Católica, uma pressão para que fosse obrigatório o ensino religioso em todas as escolas, públicas ou não. Apesar de o Decreto 19890 de 1931, conhecido como Reforma Campos, ter garantido o ensino laico, o religioso voltou a ser ministrado nas escolas públicas, no início da década de 1940, com a Reforma Capanema.

Outro compadre também ficou responsável por seu afilhado, Leonardo, mas esse, em Memórias de um Sargento de Milícias, teve experiências escolares diferentes das do pequeno Januário.

\section{Memórias de um sargento de milícias}

Memórias de um Sargento de Milícias nasceu jornal. Era a época do Folhetim, surgido na França, em 1836, com o aparecimento da imprensa e do gênero romance que revolucionou a literatura. No Brasil, nesse ano, inicia-se, com a publicação do livro de poemas Suspiros poéticos e saudades, de Domingos José Gonçalves de Magalhães, o Romantismo, momento privilegiado que foi do gênero romance. $\mathrm{O}$ folhetim veio para nossas terras, em meados do século XIX, com enorme sucesso. Eram publicados, diariamente, em jornais da capital do 
Império e jornais do interior, em espaços dedicados a entretenimento. Havia, neles, um registro da vida cotidiana, típico do jornalismo, mas não com a pretensão de registrar a verdade, afastando-se, por essa característica, da documentação histórica, apesar de serem voltados para o verossímil.

Muitos romances dessa época foram publicados, primeiramente, como Folhetim. É o caso, entre outros, de Memórias de um Sargento de Milícias, escrito pelo jornalista Manuel Antônio de Almeida (1831-1861). Almeida nasceu no Rio de Janeiro, formou-se em medicina, mas não exerceu essa profissão. Foi professor do Liceu de Artes e Ofícios daquela cidade e escritor do Correio Mercantil. Esse jornal, importante órgão de imprensa da época, possuía um suplemento literário denominado A Pacotilha, no qual este romance foi publicado, de junho de 1852 a julho de 1853. Fez tanto sucesso que apareceu em livro pouco depois: o primeiro volume, em 1854 e o segundo, em 1855, assinados por Um Brasileiro. O jornalista, seu autor, vivia o momento histórico de um Brasil recém-independente que procurava se afirmar como nação. Sua obra despertou grande interesse nas camadas mais pobres, contribuindo para a construção de uma nova identidade nacional urbana.

Zagury (1980), na apresentação da obra, nos informa que o brasileirismo de Memórias de um Sargento de Milícias toma a si a tarefa de reconstruir um passado recente, o que em muito facilitaria a compreensão e a definição do Brasil seu contemporâneo, mas nos adverte de

que não se trata, entretanto, de um romance histórico, que pretenda narrar fatos ou vidas de tonalidade heróica. É um romance de costumes, que vem a nos descrever a vida da coletividade urbana do Rio de Janeiro, na época de D. João VI. Apenas um personagem é rigorosamente histórico: o Major Vidigal - que surge como um homem comum, inserido na sociedade do seu tempo, vivendo toda sorte de problemas de uma existência normal (ZAGURY, 1980, apresentação).

O folhetim, um dos primeiros escrito no Brasil, foi esculpido em forma de memórias, no entanto, podemos entender por memórias uma narrativa em primeira pessoa, de fatos ou sentimentos passados e vividos pelo narrador. Memórias de um Sargento de Milícias, entretanto, com uma carga de verdade e outra de ficção, é uma narrativa em terceira pessoa. Isso nos fez buscar o que se entendia por memória, naquela época. Segundo o Diccionário da língua brasileira (1832), de Luiz Maria da Silva Pinto (1775 - 1869), memória seria a 
"faculdade pela qual a alma se lembra das cousas que conhece. Lembrança. Monumento. Escrito que contém narração de qualquer cousa" (PINTO, 1832, p. 710).

Chartier, citando Ricoeur, afirma que a memória "deve ser considerada como "matriz de história, na medida em que é guardiã da problemática relação representativa do presente com o passado" (RICOEUR, 2000 apud CHARTIER, 2007, p. 23), seja ela coletiva ou individual. Assim, vemos Manuel Antonio de Almeida narrando a sociedade que conhece, por meio de suas lembranças e vivências.

O início do romance nos situa, historicamente: "Era no tempo do rei" (ALMEIDA, 1980).

O começo da narrativa pode sugerir o dos contos de Fadas com o Era uma vez... . O emprego da palavra rei, sem nenhuma outra indicação, também sugere o tempo dos contos de Fadas. No entanto, embora com um final feliz, a narrativa não trata de fadas, o rei é D. João VI e o país é o Brasil. A construção da narrativa tem todos os traços da oralidade e pode ser muito útil na reconstrução dos costumes da época. Dentre as ricas informações fornecidas pelo autor, destacamos as referentes ao ensino, que aparecem logo no início do texto, quando o compadre fica responsável por Leonardo - protagonista da história e seu afilhado - e tem como projeto, torná-lo padre: "Entretanto o compadre aplicava-se a trabalhar na realização de seus intentos, e começou por ensinar o $\mathrm{ABC}$ ao menino: porém, por primeira contrariedade, este empacou no F, e nada o fazia passar adiante" (ALMEIDA, 1980, p. 38).

Almeida nos fala de uma época em que a primeira aprendizagem da leitura e escrita se fazia, no mais das vezes, em casa, dada a escassez de escolas de primeiras letras no país. Segundo pesquisas (FELIPPE, 2007), as escolas de primeiras letras funcionavam, em quase sua totalidade, na casa dos professores, não havia mobiliário adequado aos alunos e os materiais didáticos e livros eram comprados pelo professor com seus próprios recursos, pois o governo não os enviava. Essas dificuldades, mais a necessidade de ajudar, com trabalho, a família, em caso de crianças mais pobres, ocasionava grande evasão escolar.

Essa realidade apontada pelas pesquisas é elaborada, por meio da ficção, em Memórias de um Sargento de Milícias:

Com efeito foi cuidar nisso e falar ao mestre para receber o pequeno; morava este em uma casa da rua da Vala, pequena e escura.

Foi o barbeiro recebido na sala, que era mobiliada por quatro 
ou cinco longos bancos de pinho sujos já pelo uso, uma mesa pequena que pertencia ao mestre, e outra maior onde escreviam os discípulos, toda cheia de pequenos buracos para os tinteiros; nas paredes e no teto havia pendurados uma porção enorme de gaiolas de todos os tamanhos e feitios, dentro das quais pulavam e cantavam passarinhos de diversas qualidades: era a paixão predileta do pedagogo ${ }^{7}$ (ALMEIDA, 1980, p.60-61).

A necessidade de aprender o ABC, em uma sociedade em que quase a totalidade da população era analfabeta estava ligada ao desempenho de algumas funções. Neste caso, ao desejo do padrinho de tornar Leonardo padre. Enquanto os oriundos da oligarquia rural e econômica podiam almejar carreira política, tornar-se médico, advogado ou engenheiro, cursando universidades no país ou na Europa, aos despossuídos economicamente sobrava a possibilidade de pequenos cargos na carreira militar ou o sacerdócio como forma de ascensão econômica (FELIPPE, 2007).

Pelo que nos indica Almeida, em seu romance, para ser padre seria necessário ter algum conhecimento da leitura, pois o padrinho de Leonardo nos diz sobre o menino "ele nasceu mesmo para aquilo, há de ser um clérigo de truz. Vou tratar de metê-lo na escola, e depois... toca" (ALMEIDA, 1980, p. 39). Ser alfabetizado era necessário apenas para algumas profissões; a maioria da população prescindia desses requintes educacionais, sobrevivendo sem saber ler ou escrever.

Em Conto de Escola, de Machado de Assis, também publicado pela primeira vez em um jornal, Gazeta de Notícias, em 1884, portanto 31 anos depois de Memórias, a situação permanece a mesma. Mas a história se passa em 1840. E a escola também aparece como complemento necessário à realização dos sonhos que o pai de Pilar alimenta para o futuro do filho: "Era um velho empregado do Arsenal de Guerra, ríspido e intolerante. Sonhava para mim uma grande posição comercial e tinha ânsia de me ver com os elementos mercantis, ler, escrever e contar, para me meter de caixeiro" (ASSIS, 2002, p. 4).

A escola, pois, era necessária para o desempenho de algumas funções na sociedade e estaria, dessa forma, atrelada à realização de alguns sonhos projetados pelos pais. A educação tinha um fim prático, não era vista como um burilamento do ser humano.

\footnotetext{
${ }^{7}$ Segundo dicionário da época, pedagogo significava "aio, mestre de hum menino" (PINTO, 1832, p. 801).
} 
O ensino das primeiras letras, como era denominado então, devia constituir-se no saber de cor, pela ordem, as letras do alfabeto, de modo a conseguir lê-las soletrando, tal como se depreende destes trechos:

Apressemo-nos a dar ao leitor uma boa notícia: o menino desempacara do F, e já se achava no $\mathrm{P}$, onde por uma infelicidade empacou de novo. O padrinho anda contentíssimo com este progresso, e vê clarear-se o horizonte de suas esperanças; declara positivamente que nunca viu menino de melhor memória do que o afilhado, e cada lição que este da sabida de quatro em quatro dias pelo menos é para ele um triunfo (ALMEIDA, 1980, p. 36).

Com ele cresciam as esperanças do belo futuro com que o compadre sonhava para o pequeno, e tanto mais que durante este tempo fizera este alguns progressos: lia soletrando sofrivelmente, e por inaudito triunfo da paciência da comadre aprendera a ajudar missa (ALMEIDA, 1980, p. 38).

Quando o compadre chega à escola para matricular seu afilhado, Leonardo, está ocorrendo o ensino de tabuada:

Era um sábado; os bancos estavam cheios de meninos [...], chegaram os dois exatamente na hora da tabuada cantada. Era uma espécie de ladainha de números que se usava então nos colégios, cantada todos os sábados em uma espécie de cantochão monótono e insuportável, mas de que os meninos gostavam muito (ALMEIDA, 1980, p. 39).

Esse trecho nos remete à sabatina, repetição oral, realizada aos sábados, da matéria estudada durante a semana, e nos mostra o ensino por meio da memorização de uma ladainha cantada. O trecho acima nos leva também a uma época em que as escolas eram separadas em masculinas, a maioria, e femininas, e assim, vemos os "bancos cheios de meninos" (ALMEIDA, 1980, p. 39).

Os castigos escolares faziam parte dos recursos para inculcar valores, e os bons professores eram aqueles temidos devido a sua severidade na punição. Na descrição do professor, Almeida nos relata também as práticas daquele:

Era este um homem todo em proporções infinitesimais, baixinho, magrinho, de carinha estreita e chupada, excessivamente calvo; usava de óculos, tinha pretensões de latinista, e dava 6 bolos nos discípulos por dá cá aquela 
palha. Por isso era um dos mais acreditados da cidade.

[...] o mestre, acostumado àquilo, escutava impassível, com uma enorme palmatória na mão, e o menor erro que algum dos discípulos cometia não lhe escapava no meio de todo o barulho; fazia parar o canto, chamava o infeliz, emendava cantando o erro cometido, e cascava-lhe pelo menos seis puxados bolos. Era o regente da orquestra ensinando a marcar o compasso (ALMEIDA, 1980, p. 39).

Leonardo, em seu primeiro e único dia de aula na escola, levou uma dúzia de bolos. A palmatória dominava na sala de aula como o grande instrumento pedagógico da época. $\mathrm{O}$ medo era geral e em todas as referências à escola ela é destacada como o mais comum instrumento punitivo. Vale lembrar que na Lei de Diretrizes da Escola Elementar, de 10 de outubro de 1827, o artigo 15 previa a aplicação de punições. A Lei 54, de 18 de março de 1836 e o Regulamento de 25 de setembro de 1846 também autorizavam o professor a aplicá-las. Desse modo, Memórias nos conduz a uma época em que o ensino se dava prioritariamente por meio da memorização e do medo e criava novos hábitos de conduta, necessários à formação da civilidade no país recém-independente.

\section{Considerações finais}

As obras literárias escolhidas para ilustrar as discussões levantadas por nós no início do artigo revelaram, em seu tecido narrativo, fios e rastros que nos conduziram por trilhas da história. Nelas, a educação é colorida pela invenção literária de cada autor, assim, a descrição da escola de Leonardo e das escolas de Novelas Paulistanas, são calcadas nas memórias dos autores e são singulares, porém ao pesquisador em história desvelam-se como indícios de sistemas educacionais vigentes à época em que foram escritas ou à que se referiam.

As páginas da ficção, devido a seus poros acerca de usos e costumes da época em que foram escritas, suscitam no leitor uma busca por uma aporia histórica, por um acontecido, sobre o qual pesquisas acadêmicas trazem possíveis interpretações. 


\section{Referências}

ALENCASTRO, L. F.; RENAUX, M. L. Caras e modos dos migrantes e imigrantes. In: ALENCASTRO, L. F. (Org.). História da Vida Privada São Paulo: Cia das letras, 1998. p. 291-336. (Vol.2).

ALMEIDA, M. A. Memórias de um sargento de milícias. São Paulo: Ática, 1980.

ALMEIDA, M. J. Apresentação. In: XAVIER, M. E. S (Org.). A educação na literatura do século XIX. Campinas: Alínea, 2008. p. 7-10.

ASSIS, M. de. Conto de escola. São Paulo: Cosac Naify, 2002.

BRITO, A. J. A matemática e seu ensino no século XVII: dois ensaios. 2010. 100f. Tese (Doutorado em Educação) - Departamento de Educação. Universidade Estadual Paulista, Rio Claro, 2011.

BURKE, P. História e teoria social. Tradução Klauss Brandini Gerrhardt e Roneide Venâncio Majer. São Paulo: Editora UNESP, 2002.

CHARTIER, R. A história cultural entre práticas e representações. Tradução Maria Manuela Carvalho. Lisboa: Difel, 1988.

CHARTIER, R. A história ou a leitura do tempo. Tradução Cristina Antunes. Belo Horizonte: Autentica, 2007.

CURY, F. Uma história da formação dos professores de matemática das Instituições Formadoras do Estado de Tocantins. 2011. 292f. Tese (Doutorado em Educação Matemática) - Instituto de Geociências e Ciências Exatas, Universidade Estadual Paulista, Rio Claro, 2011.

FELIPPE, A. R. A. A instrução de primeiras letras na "Villa" de São Sebastião, litoral norte da Província de São Paulo. 2007. 137f. Dissertação (Mestrado em Educação) - Faculdade de Educação, Universidade São Francisco, Atibaia, 2007.

GARNICA, A. V. M. A experiência do labirinto. São Paulo: Ed. UNESP, 2008.

GARNICA, A. V. M. Analisando imagens: um ensaio sobre a criação de fontes narrativas para compreender os Grupos Escolares. Bolema, Rio Claro, v. 23, n. 35A, p. 75-100, abr. 2010.

GINZBURG, C. O fio e os rastros. São Paulo: Cia das Letras, 2007. 
LAJOLO, M. Sociedade e Literatura: parceria sedutora e problemática. In: ORLANDI, E. P.; LAJOLO, M.; IANNI, O. (Orgs.). Sociedade e linguagem. Campinas: Editora da UNICAMP, 1997.

LIMA, L. C. História, Ficção, Literatura. Tradução: Rosa Freire Aguiar e Eduardo Brandão. São Paulo: Cia das Letras, 2006.

LIMA, L. C. História. Ficção. Literatura. Uma breve apresentação. Revista Online de Literatura e Linguística, Recife, v. 1, n. 1, p. 167-176, 2011.

LOURENÇO, E.; RAZZINI, M. P. G. Leitura e formação do cidadão republicano na escola elementar paulista. In: ODALIA, N.; CALDEIRA, J. R. C. (Orgs.). História do Estado de São Paulo/formação da unidade paulista. São Paulo: Editora UNESP, 2010. (Volume 2).

MACHADO, A. A. Novelas paulistanas. Rio de Janeiro: Livraria José Olympio Editora, 1978.

MIGUEL, A.; MIORIM, M. A. História da Matemática: uma prática social de investigação em construção. Educação em Revista, Belo Horizonte. v. n/c, n. 36, p. 177-203. 2002.

ORLANDI, E. P.; LAJOLO, M.; IANNI, O. Sociedade e linguagem. Campinas: Editora da UNICAMP, 1997.

PINTO, L. M. S. Dicionário da língua brasileira. Ouro Preto: Typographia de Silva, 1832.

RIBEIRO, M. A. H. W. Machado de Assis um teatro de figuras controversas. 1989. 385f. Tese (Doutorado em Ciências da Comunicação) - Escola de Comunicações e Arte, Universidade de São Paulo, São Paulo, 1989.

RIBEIRO, D. F. C. Um estudo da contribuição de livros didáticos de Matemática no processo de disciplinarização da Matemática escolar do Colégio - 1943 a 1961. 2011. 385f. Tese (Doutorado em Educação Matemática) - Programa de Pós-Graduação em Educação Matemática, Pontifícia Universidade Católica, São Paulo, 2011.

SCHWARTZMAN, S.; BOMENY, H. M.; COSTA, V. M. R. Tempos de Capanema. São Paulo: EDUSP, 1984.

SILVA, H. Centro de Educação Matemática (CEM): fragmentos de identidade. 2006. 480p. Tese (Doutorado em Educação Matemática) - Instituto de Geociências e Ciências Exatas, Universidade Estadual Paulista, Rio Claro, 2006. 
SCHUBRING, G. Análise histórica de livros de matemática. Tradução: Maria Laura M. Gomes. Campinas: Autores Associados, 2003.

VIDAL, D. G.; FARIA FILHO, L. As lentes da história: estudos de história e historiografia da educação no Brasil. Campinas: Autores Associados. 2005.

WHITE, H. Method and Ideology in Intellectual History: The case of Henry Adams. In: LaCapra, D.; Kaplan, S. (Eds). Modern European Intellectual History reappraisals \& new perspectives. Ithaca: Cornell University Press, 1987. p.280 - 310.

ZAGURY, E. Apresentação. In: ALMEIDA, M. A. Memórias de um sargento de milícias. São Paulo: Ática, 1980.

Submetido em Maio de 2012. Aprovado em Julho de 2012. 